\title{
超高強度硬化体の強度・変形特性における空隙構造と水分の働き EFFECT OF PORE STRUCTURE AND EVAPORABLE-WATER ON STRENGTH AND DEFORMABILITY OF ULTRA-HIGH-STRENGTH PASTE
}

\author{
松田 拓*, 野口貴 文**, 蓮尾孝一***, 小出貴夫****, 鈴木康範 \\ Taku MATSUDA, Takafumi NOGUCHI, Koichi HASUO, \\ Takao KOIDE and Yasunori SUZUKI
}

\begin{abstract}
In this study, paste with a strength of over $200 \mathrm{MPa}$ made using low-heat portland cement and silica fume was subjected to thermal histories with different maximum temperatures to confirm the development properties of strength, autogenous shrinkage, and pore structure. By clarifying changes in the pore structure under different thermal histories, the authors considered the effect of pore structure and evaporable-water on the strength and deformability. Furthermore, the function of micro-pores inaccessible to nitrogen or helium molecules and "unbound water" present in such micro-pores was considered.
\end{abstract}

Keywords : Ultra-High-Strength, Silica Fume, Pore Structure, Evaporable-Water, Inkbottle Pores 超高強度，シリカフューム，空隙構造，蒸発可能水，インクボトル空隙

\section{1. はじめに}

ポルトランドセメントに高純度の非晶質シリカ質微粉末を混合し た結合材を用いた超高強度コンクリートの圧縮強度（強度）や自己 収縮ひずみ（自己収縮）の特性は，初期材齢時の水和反応に伴う温 度条件（初期高温履歴）に大きく影響される例え侍1)。筆者らの研究 によると，超高強度コンクリートの強度と自己収縮は，最高温度 $\left(T_{\max }\right)$ が高くなると急激に増進するため，実務においては強度・ 自己収縮の予測式を，初期高温履歴を受けたもの $\left(T_{\max } \geqq 60^{\circ} \mathrm{C}\right)$ と そうでないもの $\left(T_{\max } \leqq 45^{\circ} \mathrm{C}\right)$ とで使い分けることが有効である ${ }^{1) 2}$ 。 また, 超高強度コンクリートの圧縮クリープひずみの進行速度は初

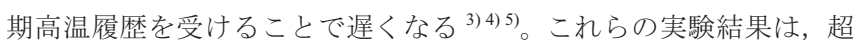
高強度ペーストの硬化体（超高強度硬化体）の水和物組成や空隙構 造が特定の温度条件で変化することを示唆する。その機構の解明は, 構造体コンクリートの強度管理やひび割れ検証に加え, 構造物の変 形や而勺性の長期予測，実験式でなくメカニズムに立脚した反応モ デルの構築，新材料開発など材料設計手法の発展に資する。

筆者らは既報 6) 7) 899)で， $T_{\max }$ の異なる初期高温履歴条件下におけ る超高強度ペーストの強度, 自己収縮, 水和物量, 一軸拘束応力, 見かけ密度等の時間変化を確認し, 温度上昇時において特定の閾値 温度に達するとそれらが不連続的に変化することを示し，その
理由を考察した。

本稿では，1）既報 6978)99の実験時に採取したペースト試料を分析 することで超高強度硬化体の空隙構造への初期高温履歴の影響を整 理し，2）そのことが温度降下後の強度・自己収縮，圧縮変形特性一 及ぼす影響を水分移動の観点から議論する。更に 3) 窒素およびへ リウム分子が浸入出来ない空隙およびその中に存在する「結合して いない水」の働きを考察し，今後取り組まれるべき課題を述べる。実 験概要と結果には，必要な範囲で既報 6)778) 9)の内容を再掲する。

\section{2. 実験概要}

使用材料を表 1 に示す。結合材は低熱ポルトランドセメントとシ リカ質微粉末と早強ポルトランドセメントを質量比 $7: 2: 1$ で混合 したものを使用した。本研究で使用したシリカ質微粉末は，JIS A 6207 に規定されたシリカフュームと比べBET 比表面積が小さいが， $\mathrm{SiO}_{2}$ 含有量は同等以上である。水結合材比は $0.13, T_{\max }$ の水準は、 $20 ， 45 ， 60 ， 90^{\circ} \mathrm{C}$ とした（表 2）。圧縮強度試験体は $\phi 50 \times 100 \mathrm{~mm}$ 円柱とした。自己収縮は，100×100×400mm の角柱の中心に熱電対内 蔵型埋込み型ひずみ計を設置し測定した。打設後に各試験体を封か んし， $20^{\circ} \mathrm{C}$ に制御した温度可変制御槽内で養生し，凝結始発時に温. 度上昇を開始した $\left(2.92^{\circ} \mathrm{C} / \mathrm{Hr}\right)$ 。所定の温度で各試験体を取り出し,

\footnotetext{
本研究の一部は文献 6) 7) 8) 9) に掠いて発表している。

三井住友建設侏技術研究開発本部技術開発センター 主任研究員・博士(工学)

** 東京大学大学院工学系研究科建築学専攻 准教授·博士 (工学)

*** 三井住友建設(株)技術研究開発本部技術開発センター グループ長

**** 住友大阪セメント(侏セメント・コンクリート研究所

***** 住友大阪セメント(株)セメン・コンクリート研究所 技師長・博士 (工学)
}

Senior Researcher, Technical Research and Development Center, Technology and Research Development Division, Sumitomo Mitsui Construction Co., Ltd., Dr. Eng.

Assoc. Prof., Dept. of Architecture, Graduate School of Eng., The University of Tokyo, Dr. Eng.

Chief, Technical Research and Development Center, Technology and Research Development Division, Sumitomo Mitsui Construction Co., Ltd.

Research Engineer, Cement/Concrete Research Laboratory, Sumitomo Osaka Cement Co., Ltd.

Chief Technology Manager, Cement/Concrete Research Laboratory, Sumitomo Osaka Cement Co., Ltd., Dr. Eng. 
表 1 使用材料

\begin{tabular}{|c|c|c|}
\hline \multicolumn{2}{|c|}{ 名称および種類 } & 物性 \\
\hline \multirow{3}{*}{$\begin{array}{l}\text { 結合材 } \\
\text { (B) }\end{array}$} & $\begin{array}{c}\text { 低熱ポルトランド } \\
\text { セメント(L) }\end{array}$ & $\begin{array}{l}\text { 密度: } 3.24 \mathrm{~g} / \mathrm{cm}^{3}, \\
\text { 比表面積 : } 3300 \mathrm{~cm}^{2} / \mathrm{g}, \mathrm{C}_{2} \mathrm{~S}: 55 \%\end{array}$ \\
\hline & $\begin{array}{c}\text { 早強ポルトランド } \\
\text { セメント }(\mathrm{H})\end{array}$ & $\begin{array}{l}\text { 密度: } 3.13 \mathrm{~g} / \mathrm{cm}^{3}, \\
\text { 比表面積 : } 4550 \mathrm{~cm}^{2} / \mathrm{g}, \mathrm{C}_{3} \mathrm{~S}: 66 \%\end{array}$ \\
\hline & シリカ質微粉末(SF) & $\begin{array}{l}\text { 表乾密度 : } 2.25 \mathrm{~g} / \mathrm{cm}^{3}, \\
\text { 比表面積 : } 10.2 \mathrm{~m}^{2} / \mathrm{g}, \mathrm{SiO}_{2}: 96.0 \%\end{array}$ \\
\hline \multirow{2}{*}{$\begin{array}{c}\text { 化学 } \\
\text { 混和剤 }\end{array}$} & 高性能減水剤(SP) & ポリカルボン酸系 \\
\hline & 消泡剂(NonAE) & ポリオキシアルキレンアルキルエーテル系 \\
\hline
\end{tabular}

表 2 最高温度 $T_{\text {max }}$ の水準

\begin{tabular}{|c|c|c|c|}
\hline \multicolumn{3}{|c|}{ 練上がり温度 $T_{0}\left[{ }^{\circ} \mathrm{C}\right]$} & 最高温度 $T_{\max }\left[{ }^{\circ} \mathrm{C}\right]$ \\
\hline \multicolumn{3}{|c|}{20} & $20,45,60,90$ \\
\hline \multicolumn{4}{|c|}{ 表 3 試料の前処理方法 } \\
\hline 分析試験の種類 & 粒径 $[\mathrm{mm}]$ & & 前処理方法 \\
\hline 結合水率 & $2.5-1.2$ & & $105^{\circ} \mathrm{C}$ 乾燥（恒量まで） \\
\hline $\mathrm{Ca}(\mathrm{OH})_{2}$ & $2.5-1.2$ & \multirow{4}{*}{\begin{tabular}{|l} 
アセトン \\
水和停止
\end{tabular}} & D-乾燥 (約 $13 \mathrm{~Pa}$ 減圧状態 $60 \sim 120$ 時間) \\
\hline 見かけ密度 & 1.2 以下 & & $105^{\circ} \mathrm{C}$ 乾燥 (48時間) \\
\hline 水銀圧入法 & $2.5-1.2$ & & D-乾燥 (約 $13 \mathrm{~Pa}$ 減圧状態 $60 \sim 120$ 時間) \\
\hline 窒素ガス吸着法 & 1.2 以下 & & $105^{\circ} \mathrm{C}$ 乾燥 (48時間) \\
\hline
\end{tabular}

6 面周囲を断熱材で覆い緩やかに温度降下させた。 $T_{\max }=90^{\circ} \mathrm{C}$ 試験体 の温度は, $90^{\circ} \mathrm{C}$ 到達後に槽内温度を $0.25^{\circ} \mathrm{C} / \mathrm{Hr}$ で下げることで制御 した。各試験体は温度降下後 $20^{\circ} \mathrm{C}$ 一定で養生した。

所定の材齢で強度用試験体を槽より取り出し, 圧縮試験（5 本平 均）を実施した。強度試験材齢は $0.8 \sim 1.6 ， 5 ， 14 ， 28 ， 47,91$ 日 とした。自己収縮は各水準で 1 体の試験体について, 材齢 240 日ま で測定した。圧縮試験後の破片を粉砕・分級し, 結合水率（恒量ま で $105^{\circ} \mathrm{C}$ 乾燥した際の未蒸発水質量 / 結合材質量 $\left.[\%]\right), \mathrm{Ca}(\mathrm{OH})_{2}$ 含有 量（TG-DTA による $\mathrm{Ca}(\mathrm{OH})_{2}$ 質量／ペースト硬化体質量[\%])，見か け密度 (ヘリウム $(\mathrm{He})$ ガスによる気相置換法), 水銀圧入法によ る細孔径分布 $(3.6 \mathrm{~nm} \sim 200 \mu \mathrm{m})$, 窒素ガス吸着法（ $\mathrm{N}_{2}$ 吸着法）によ る細孔径分布（BJH 法 ${ }^{10)} ， 2.6 \sim 187 \mathrm{~nm}$ ）および BET 比表面積を測 定した。吸着質に水蒸気でなく窒素ガスを用いた理由は, 初期材齢 での測定時に未反応結合材と水蒸気とが反応（化学吸着）すること

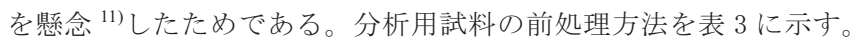

\section{3. 実験結果および考察}

図 1 は，(a)の温度履歴を与えた場合の，(b) 有効材齢または結合 水率と圧縮強度, 自己収縮, $\mathrm{Ca}(\mathrm{OH})_{2}$ 含有量との関係, (c) 有効材 齢とみかけ密度および BET 比表面積との関係を示したものである。

\section{1 強度と自己収縮および $\mathrm{Ca}(\mathrm{OH})_{2}$ 含有量の変化}

図 1 (a) (b)を見ると，

1) $T_{\max }$ が $45 \sim 60^{\circ} \mathrm{C}$ の間にある閾值温度を超えると強度・自己収縮が 急激に増進し, 両者と有効材齢との関係は $T_{\max }$ が閾值温度を超え たものとそうでないものそれぞれで同一曲線となる。閾值温度を 超えたものの強度・自己収縮増進は, 温度降下以降に停滞寸る。

2) $T_{\max }$ が閾值温度を超えると $\mathrm{Ca}(\mathrm{OH})_{2}$ 含有量が急激に減少する。す なわち，ポゾラン反応が急激に活発に行われる。

3) $T_{\max }$ が閾值温度を超えて強度・自己収縮・ $\mathrm{Ca}(\mathrm{OH})_{2}$ 含有量が急激に 変化する時点では結合水量の増加量が少ない。

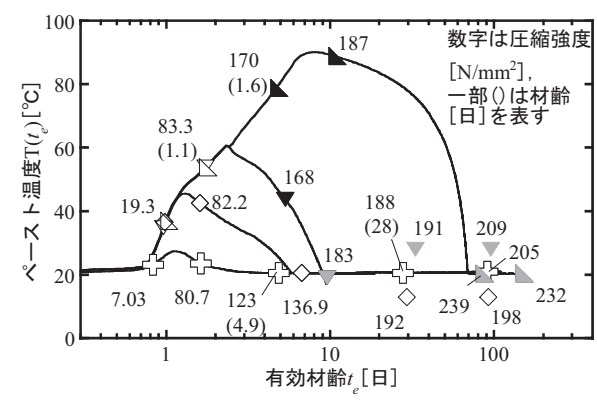

（a）温度履歴と圧縮強度との関係

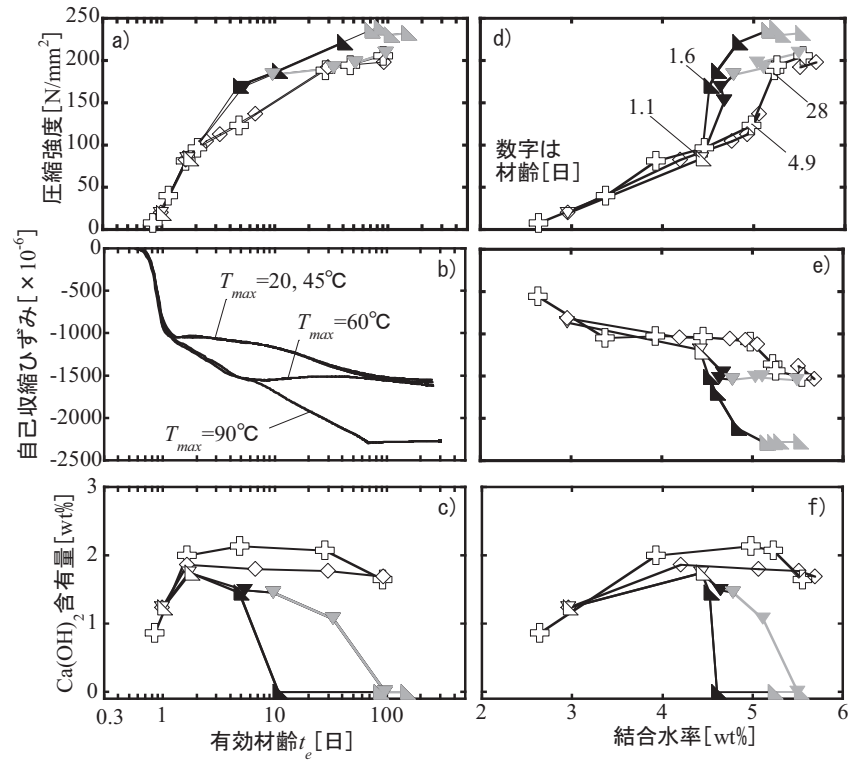

（b）有効材齢および結合水率と諸物性值との関係

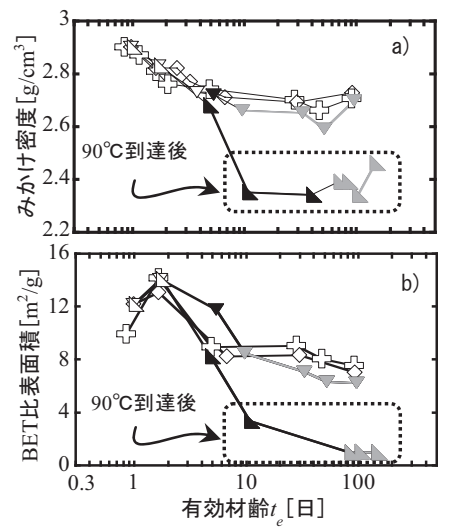

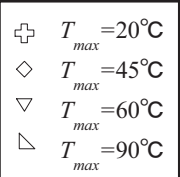

黒色 : $60^{\circ} \mathrm{C}$ 到達後で 温度降下以前 灰色: $60^{\circ} \mathrm{C}$ 到達後で かつ温度降下後
（c）有効材齢と見かけ密度およびBET 比表面積との関係 図 1 諸物性值の測定結果

筆者らは既報 ${ }^{6778)}$ におおて, 閾值温度に達した時点での不連続的 な変化の理由として，1) エトリンガイトからの水の放出によるポゾ ラン反応活発化，2) 緻密で比表面積の大きいポゾラン由来の C-S-H が急激に生成され空隙を充填（強度増進），3）エトリンガイトのペ 一ス卜拘束効果の減少と $\mathrm{Ca}(\mathrm{OH})_{2}$ の体積減少（自己収縮増進）を考 察し, 初期高温履歴条件下でのエトリンガイト量や一軸拘束挙動の 測定結果から，この考察に矛盾しない結果を得た。ただし既報 ${ }^{6) 798)}$ では， $T_{\max }$ が閾值温度を超えたものの強度・自己収縮が温度降下以 降に停滞する理由には言及していない。 


\section{2 見かけ密度と BET 比表面積の変化}

図 1 (c) を見ると, $\mathrm{He}$ ガス気相置換による見かけ密度と $\mathrm{N}_{2}$ ガス吸 着法による BET 比表面積は, ともに $90^{\circ} \mathrm{C}$ 到達後の測定值が急激に 小さくなる。どちらの測定も, $\mathrm{He}$ もしくは $\mathrm{N}_{2}$ 気体分子が自身の寸 法以上の空隙全てに到達しないと, 測定值は真值より小さくなる (気 相置換法では試料体積を過大評価するため)。すなわち今回の測定で は, $90^{\circ} \mathrm{C}$ 到達後の試料については $\mathrm{He}$ および $\mathrm{N}_{2}$ 気体分子は自身の寸 法以上の空隙全てには到達していないと考えられる。 $\mathrm{N}_{2}$ と $\mathrm{He}$ の寸 法は約 $0.30 \mathrm{~nm}$ (分子動力学的直径 ${ }^{12}$ )でそれぞれ $0.260,0.364 \mathrm{~nm}$ )で ある。 $90^{\circ} \mathrm{C}$ 到達後の試料は約 $0.30 \mathrm{~nm}$ より微細な空隙が多量に形成 され，粗大な空隙はその中に独立的に分散すると考えられる。

\section{3 細孔径分布の変化}

水銀圧入法と $\mathrm{N}_{2}$ 吸着法による細孔径分布の測定結果を図 2 に示 す。水銀圧入法の結果は細孔径 $200 \mathrm{~nm}$ より大きい空隙に変化が見ら れないため，全ての測定結果を $2.0 〜 200 \mathrm{~nm}$ のレンジで表示する。

水銀圧入法と $\mathrm{N}_{2}$ 吸着法の測定結果には, 「物質が繰り返し出入り できる移動経路 (連続空隙)」と「入り口が狭く奥に広がる形状で, 一度浸入した物質が再び抜け出しにくくそれぞれの独立性が高い空 隙 (インクボトル空隙 $\left.{ }^{13)}\right) 」 の$ 影響が含まれる。水銀圧入法では, 大きな空隙から小さな空隙へと順次水銀が浸入すると仮定される。
また $\mathrm{N}_{2}$ 吸着法では, 吸着段階でインクボトル空隙内を満たした吸着 質（窒素）は減圧過程では吸着時より相対圧を下げないと脱着され ない。つまり空隙がインクボトル状の場合, 水銀圧入法と $\mathrm{N}_{2}$ 吸着法 （脱着側）の測定結果は大径の空隙を多量な微細空隙と評価する。 一方， $\mathrm{N}_{2}$ 吸着法（吸着側）の結果はこうした影響のない結果が得ら れるとされている ${ }^{14)}$ 。図 2 において，(a) 水銀圧入法の測定結果と (c) $\mathrm{N}_{2}$ 吸着法（脱着側）の測定結果は両者とも (b) $\mathrm{N}_{2}$ 吸着法（吸着 側）の結果に比べ微細空隙が多く測定されており，両者の細孔径分 布は概ね一致している。以上より，本研究では「 $\mathrm{N}_{2}$ 吸着法（吸着側） で得られた結果を連続空隙」,「 $\mathrm{N}_{2}$ 吸着法（脱着側）および水銀圧入 法で得られた結果をインクボトル空隙の影響が含まれた結果」とし て議論を進める。また前述したように， $90^{\circ} \mathrm{C}$ 到達後の試料の細孔径 分布は「 $\mathrm{N}_{2}$ 分子が自身の寸法以上の空隙全てには到達せずに得られ た結果」と考え, $90^{\circ} \mathrm{C}$ 到達前後の結果を比較した考察は行わない。

\section{3. 1 初期高温履歴による連続空隙構造の変化}

図 $2(\mathrm{~b})$ で $T_{\max }=20,45,60^{\circ} \mathrm{C}$ の結果について約 $170 \mathrm{~N} / \mathrm{mm}^{2}$ の強度 発現以降を見ると $\left(T_{\max }=90^{\circ} \mathrm{C}\right.$ の結果は $90^{\circ} \mathrm{C}$ 到達後のため比較しな い), 約 20〜30nm をピークとしたまま約 20nm 以下の空隙が埋まる。 一般的なセメント硬化体は反応につれピーク細孔径が微細領域にシ フトしたとえば 15) 16)，「粗大空隙が細分化され微細空隙の比率が増加す
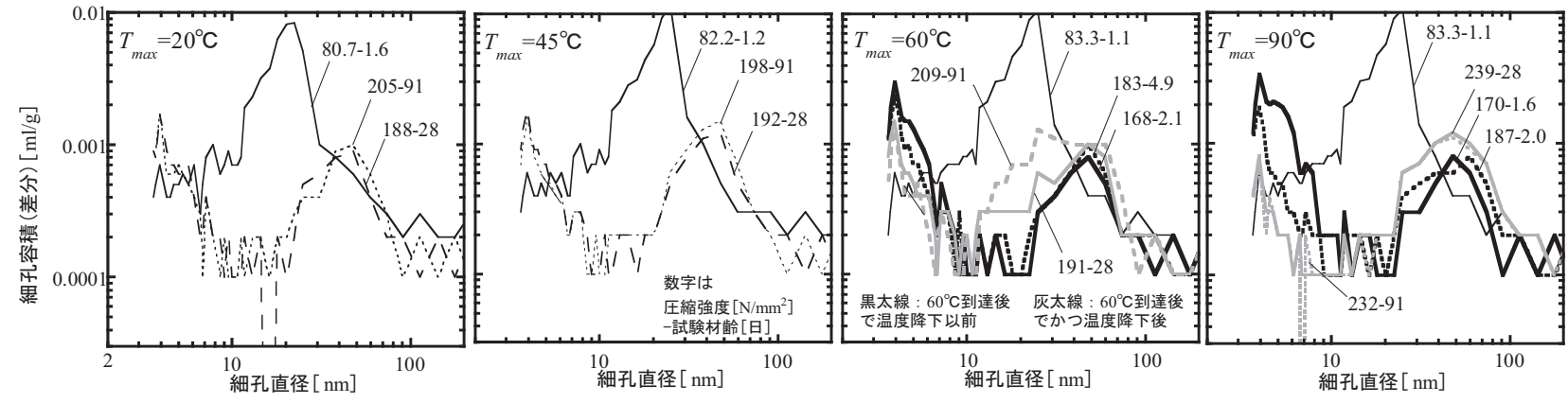

（a）水銀圧入法の結果
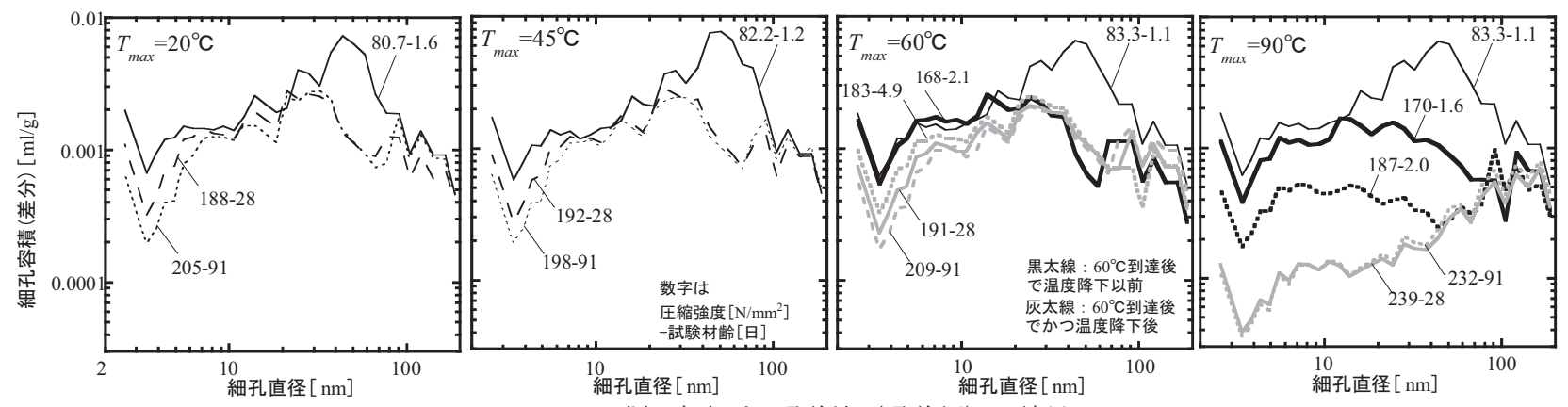

（b）窒素ガス吸着法（吸着側）の結果
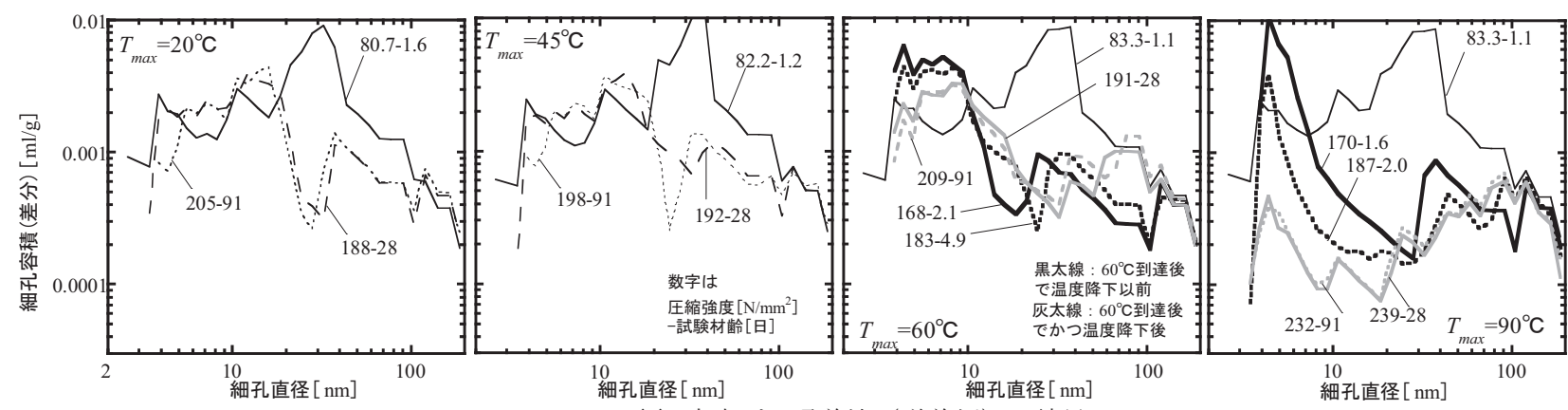

（c）窒素ガス吸着法（脱着側）の結果

図 2 細孔径分布 


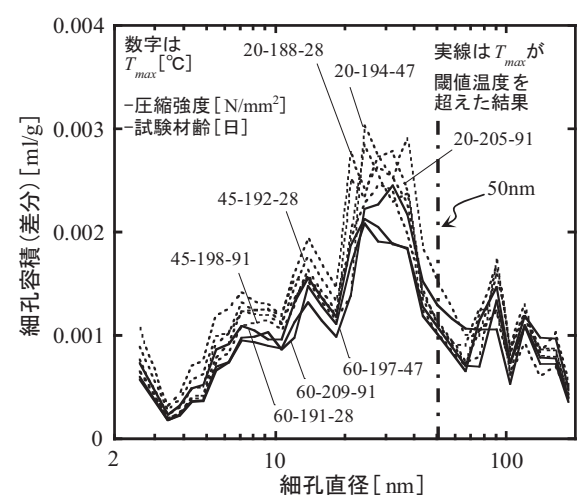

図 3 窒素ガス吸着法 (吸着側) による細孔径分布 （異なる $T_{\max }$ で強度が同等のものを抽出）

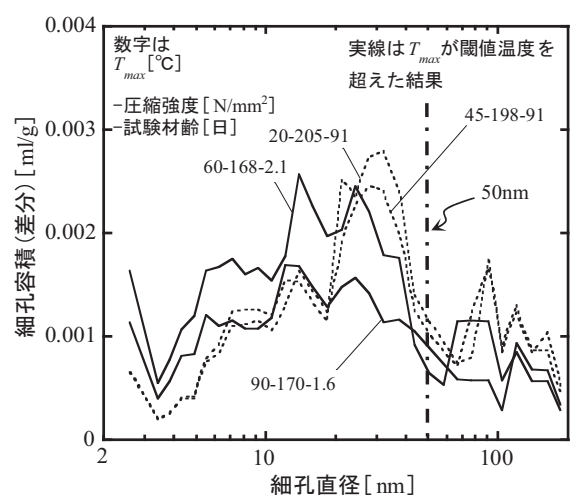

図 4 窒素ガス吸着法（吸着側）による細孔径分布

(閾值温度を超えた直後と閾值温度を超えずに長期材齢経過した結果の比較)
る」と考えられている。しかし, 本研究対象の超高強度硬化体ではそ れと異なり, ある程度反応が進行すると水和物が粗大な空隙に析出 しにくくなっている。この理由を考察する。外部から水の供給が制 限される条件で反応が進行する場合, 水が消費される場所で空隙構 造は微細化し, 化学ポテンシャル ${ }^{177}$ の変化により自由水は微細領域 に向かい移動する。その結果空隙は粗大領域から乾燥し, 自由水は 主として微細領域に存在寸ると考えられる。一方, 水和反応が液相 の水を介することは従来知から知られているたと将 18$)$ 。すなわち, 「超高強度硬化体の場合, 封かん状態で反応が進行すると約 $20 \mathrm{~nm}$ 以 上の領域では反応に必要な水が不足する」と考えることができる。 また, 過去に五十嵐らが $W / B=0.60 \sim 0.25$ の範囲でペーストの構成 相を画像解析した研究 $\left.{ }^{19}\right)$ では, 低 $W / B(=0.25)$ では反応が進行す ると $200 \mathrm{~nm}$ 以下の微細空隙が埋まり粗大空隙が残存している。本実 験結果から, 超低 $W / B$ 条件ではこれと同様な現象が, より微細な領 域で起こるとわかった。すなわち, 封かん状態で反応が進行する場 合, 低 $W / B$ 条件ほど反応に必要な水は微細な領域に存在し, 粗大空 隙は残存するものの空隙領域は微細側にシフトすると考えられる。

次に, $T_{\max }$ の異なる試験結果から強度レベルが同等 $\left(200 \mathrm{~N} / \mathrm{mm}^{2}\right.$ 程 度）のものを抽出し図 3 に示す。全体的に見て, $T_{\max }=60^{\circ} \mathrm{C}$ 条件（闇 值温度を超えた条件）の細孔径分布は概衫 $50 \mathrm{~nm}$ 以下の空隙が少な い。また図 4 は, $T_{\max }=20,45^{\circ} \mathrm{C}$ 条件は長期材齢 91 日, $T_{\max }=60,90^{\circ} \mathrm{C}$ 条件は材齢 2 日以内かつ $60^{\circ} \mathrm{C}$ 到達以降のものである $\left(T_{\text {max }}=90^{\circ} \mathrm{C}\right.$ 条 件は $90^{\circ} \mathrm{C}$ 到達前の試料のため比較できる)。 $T_{\text {max }}=60,90^{\circ} \mathrm{C}$ 条件は $T_{\max }=20,45^{\circ} \mathrm{C}$ 条件に比べ強度発現が小さいものの, この時点で既に ピーク細孔径が $T_{\max }=20,45^{\circ} \mathrm{C}$ 結果よりも微細領域にシフトしてい る。本検討より， $T_{\text {max }}$ が $45 \sim 60^{\circ} \mathrm{C}$ の間にある閾值温度に達すると, 直径 $50 \mathrm{~nm}$ 以下の範囲で「閾值温度を超えない条件では埋まらない 領域が埋まる」と考えられる。

\section{3. 2 初期高温履歴によるインクボトル空隙構造の変化}

菅俣らの研究 ${ }^{20}$ によると, 超高強度硬化体の空隙構造は総じてイ ンクボトル状である。 $\mathrm{N}_{2}$ 吸着法による吸脱着等温線（図 5）を見る とヒステリシス挙動は材齢につれ明瞭となり, 長期材齢での空隙構 造は $T_{\max }$ によらずインクボトル状であるとわかる。 $T_{\max }=20,45^{\circ} \mathrm{C}$ の場合のヒステリシス挙動は, 材齢 28 日以降目立った変化がない。 注目す心゙きは $T_{\max }=60,90^{\circ} \mathrm{C}$ 場合のヒステリシス挙動であり, $60^{\circ} \mathrm{C}$ を超えた時点（図1(a)の強度発現を参照) で著しく明瞭となる。空 隙の連続性が低いほど, その中を満たした $\mathrm{N}_{2}$ 分子の脱着に要する相
対圧低下量は大きくなるため, ヒステリシスは明瞭となる。本結果 から,「閾值温度に達すると空隙の連続性が著しく低下し, その中に 一旦浸入した物質が脱出しにくくなる」ことがわかる。

次に， $T_{\max }$ が闇值温度を超えたものとそうでないものとについて, 長期材齢における空隙の連続性と空隙寸法および $T_{\text {max }}$ との関係を整 理する。検討手順を以下 1) 4)および図 6 に示す。

1) 吸着量の各実測值の相対圧 $P / P_{0}=1.0$ 時の值に対寸る比率（本研 究では吸着率 $[\%]$ と呼称）を求める。

2)「吸着時の吸着率と同等まで $\mathrm{N}_{2}$ 分子を脱着させるために必要な 相対圧の低下量」 $\triangle P / P_{0}$ を求める。

3) 横軸に $P / P_{0}$, 縦軸に $\triangle P / P_{0}$ としてプロットする。

4) $\Delta P / P_{0}$ が大きいほど,「当該 $P / P_{0}$ で定義される細孔径をネックと したインクボトル形状が複雑（すなわち空隙の連続性が低い）」 と評価する。

検討結果のうち, 強度レベルが同等 $\left(200 \mathrm{~N} / \mathrm{mm}^{2}\right.$ 程度 $)$ のものを 抽出し図 7 に示寸。これを見ると, 吸着後の脱着過程において $P / P_{0}$ $\doteqdot 0.96$ 付近から $T_{\text {max }}=60^{\circ} \mathrm{C}$ 条件の $\triangle P / P_{0}$ は $T_{\max }=20,45^{\circ} \mathrm{C}$ 条件に比 べ明らかに大きい。吸着質が $\mathrm{N}_{2}$ の場合, $P / P_{0} \fallingdotseq 0.96$ に対応する空隙 の直径を $\mathrm{BJH}$ 法で求めると約 $50 \mathrm{~nm}$ となる。すなわち， $T_{\max }$ が閾值 温度を超えた超高強度硬化体は, 長期材齢において直径 $50 \mathrm{~nm}$ 以下 の範囲で空隙の連続性がより低いと考えられる。なお, 一般にメソ 孔のヒステリシスが低圧側で閉じる理由は，吸着質が凝縮する細孔 が Kelvin式の成立する毛細管凝縮が起こらないほどに小さくなるた めと考えられている ${ }^{21)}$ 。従って, 図 5 でヒステリシスが閉じた以降 の結果 $\left(P / P_{0}\right.$ で約 0.4 以下, 空隙直径では約 $2.6 \mathrm{~nm}$ （測定下限）以 下）は，これがインクボトル状でないと示寸ものではない。 $2.6 \mathrm{~nm}$ 以下の空隙構造は現時点で未確認だが， $2.6 \mathrm{~nm}$ を境にインクボトル 状でなくなることは無いであろうと推察している。

前述したように, 本研究対象の超高強度硬化体は $T_{\text {max }}$ が閾值温度 に達した時点で急激なポゾラン反応が起こり, ポゾラン由来の緻密 で比表面積の大きい C-S-H が生成されると考えている。これが連続 空隙の充填および連続性低下の理由と推察される。一方, シリカ質 微粉末を使用しない, ポルトランドセメント系のコンクリートにつ いても, 特定の閾值温度を境界として空隙構造が変化することが報 告されている。半井らの研究 ${ }^{22}$ によれば, $30 \sim 60^{\circ} \mathrm{C}$ より高い温度条 件では常温で埋まらない微細空隙が埋まる。すなわち, 閾值温度を 超えたときに起こる超高強度硬化体の空隙構造変化は, 「セメント硬 
化体の空隙構造の変化（シリカ質微粉末が存在しない系）」と, $\left\lceil\mathrm{Ca}(\mathrm{OH})_{2}\right.$ の急激な消失と緻密な C-S-H の急激な生成（シリカ質微 粉末が存在する系) 」との複合と考えられ, その機構を今後解明する 必要がある。
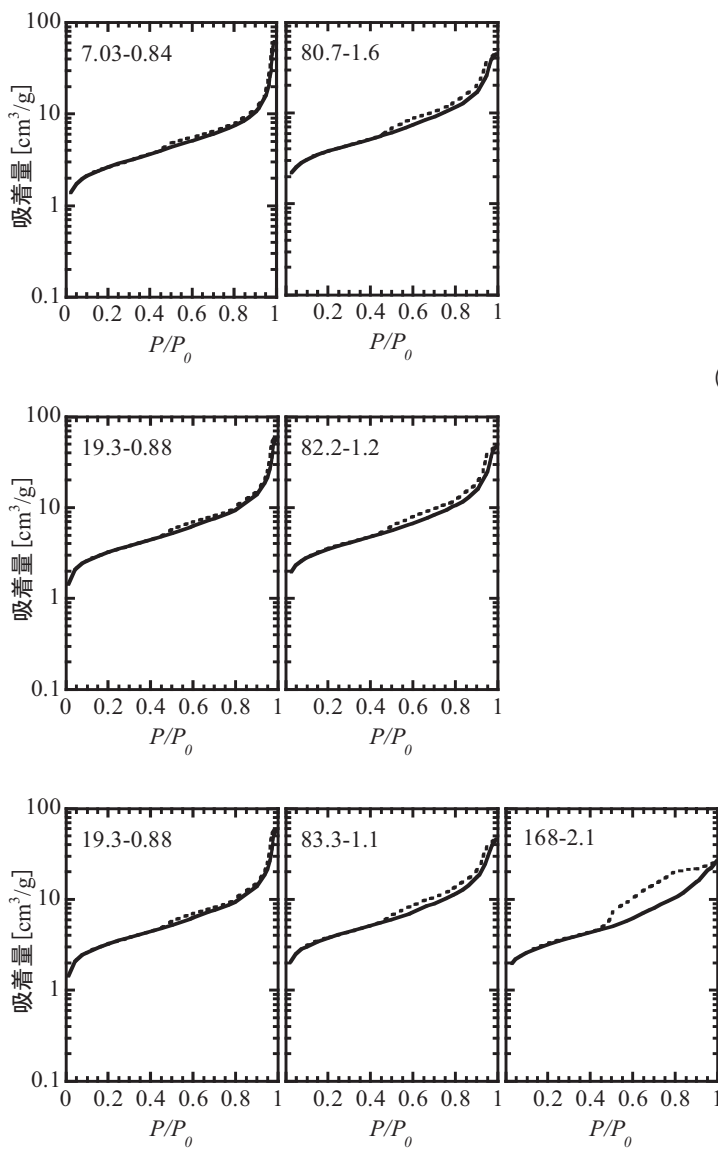

\section{$3.4105^{\circ} \mathrm{C}$ 蒸発可能水の蒸発速度と空隙構造との関係}

結合水率測定時に得た, $105^{\circ} \mathrm{C}$ 蒸発可能水率 $\left(105^{\circ} \mathrm{C}\right.$ 蒸発可能水量 結合材質量 $[\%] ）$ の測定例を図 8 に示す。図中には, $T_{\text {max }}=20^{\circ} \mathrm{C}$ 条 件と $T_{\max }=60^{\circ} \mathrm{C}$ 条件それぞれの材齢 47,91 日の結果に加え, $T_{\max }=90^{\circ} \mathrm{C}$

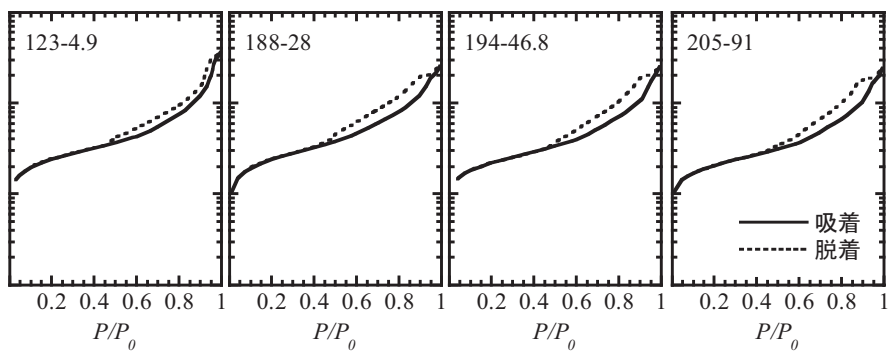

(a) $T_{\max }=20^{\circ} \mathrm{C}$ 条件の結果
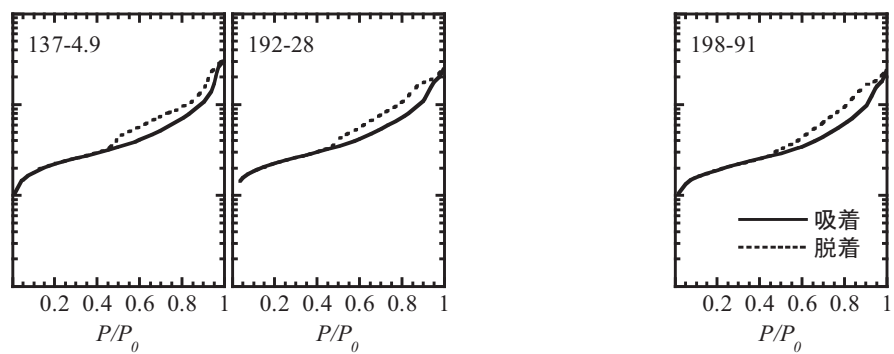

(b) $T_{\max }=45^{\circ} \mathrm{C}$ 条件の結果
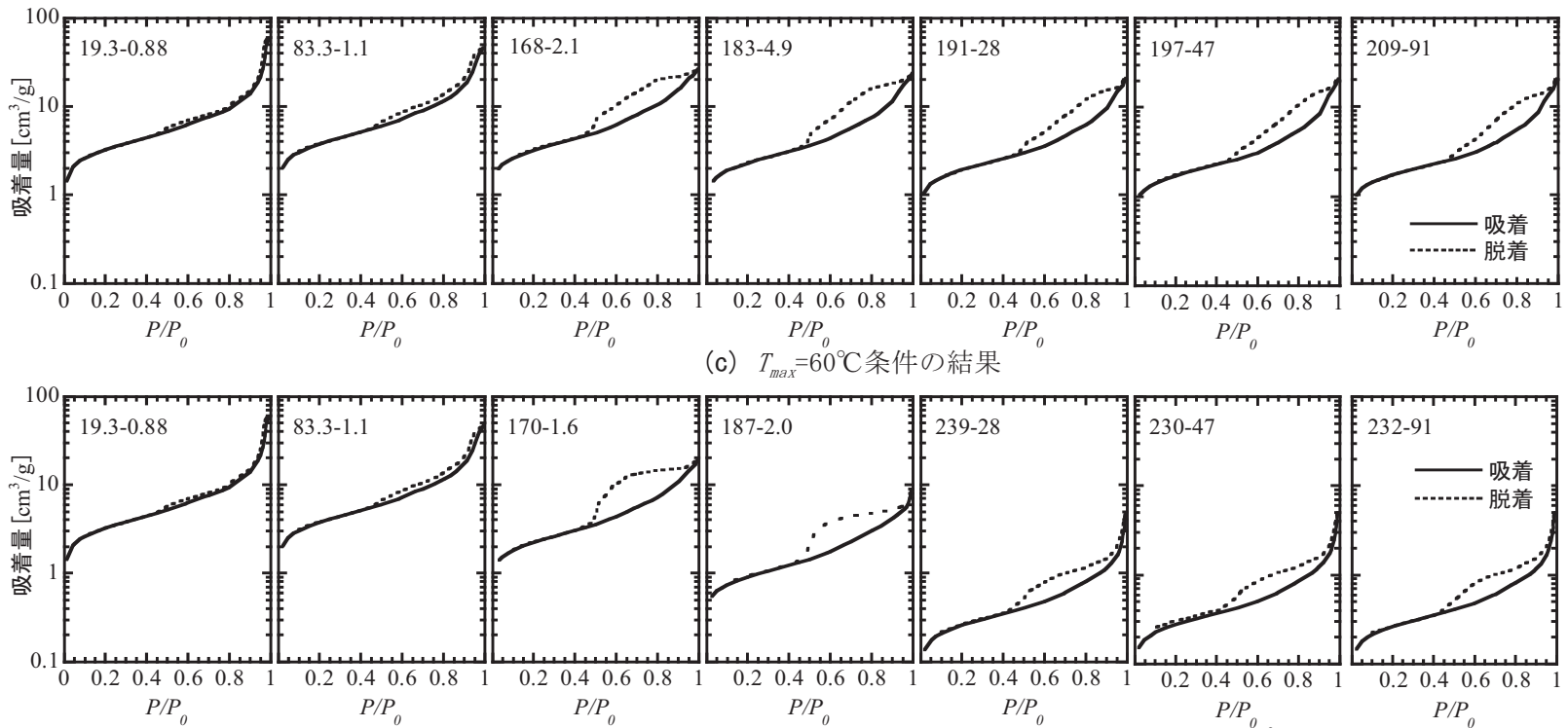

(d) $T_{\max }=90^{\circ} \mathrm{C}$ 条件の結果 数字は圧縮強度 $\left[\mathrm{N} / \mathrm{mm}^{2}\right]$-試験材齢[日]を示す

図 5 吸脱着等温線

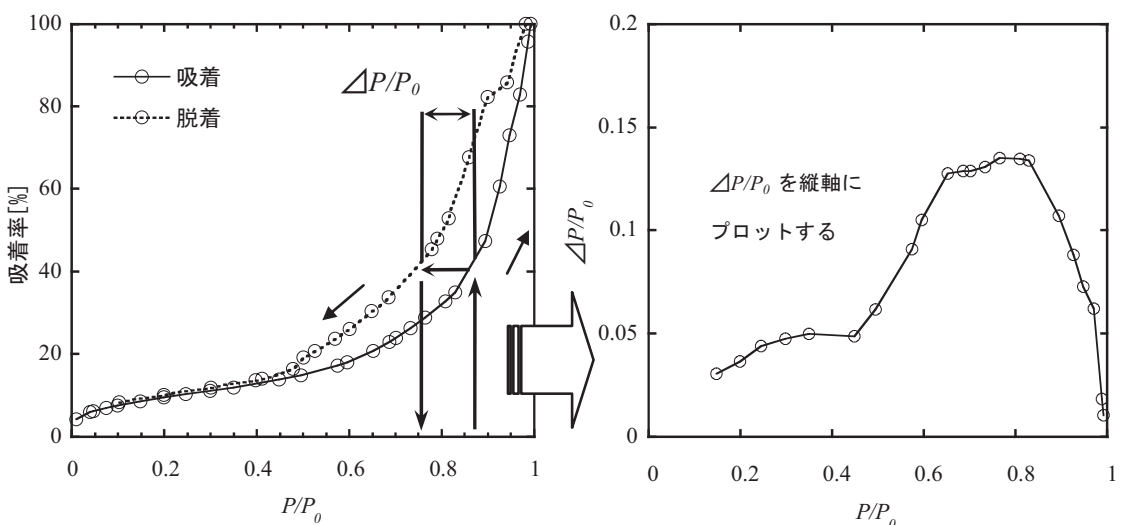

図 6 検討手順 $\left(\Delta P / P_{0}\right.$ の求め方 $)$

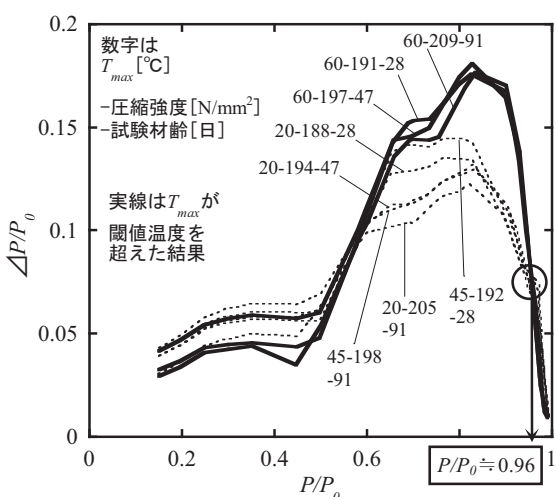

図 $7 T_{\max }$ の異なる超高強度硬化体の $P / P_{0}-\triangle P / P_{0}$ 関係 


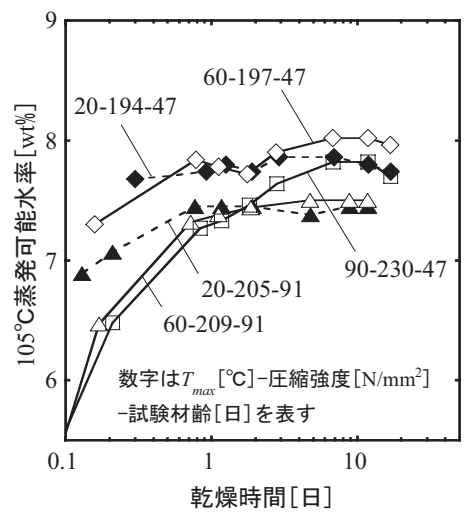

図 $8105^{\circ} \mathrm{C}$ 蒸発可能水量の測定例

条件の材齢 47 日の結果を示す。これを見ると, 強度が同等であって も $T_{\max }=60^{\circ} \mathrm{C}$ 条件は $T_{\max }=20^{\circ} \mathrm{C}$ 条件よりも蒸発に時間を要している。 また $T_{\max }=90^{\circ} \mathrm{C}$ 条件 $\left(47\right.$ 日） は， $T_{\max }=20,60^{\circ} \mathrm{C}$ 条件の材齢 47 日お よび 91 日と比較して明らかに蒸発に時間を要している。これらの理 由は, 3. 3.1 と 3. 3.2 の検討から次のように説明できる。すなわち,

1) $T_{\max }$ が閾值温度を超えると $50 \mathrm{~nm}$ 以下の空隙範囲で常温条件で は埋まらない領域が埋まり, 空隙の連続性が低下寸る。

2) その結果, 微細空隙に存在する自由水が外部に脱出しにくくなる。 3) その傾向は $T_{\max }$ が高いほど著しくなる。

\section{4. 超高強度硬化体の強度·変形特性における空隙構造と水分の働き}

\section{1 温度降下以降の強度 - 自己収縮増進の停滞}

$T_{\text {max }}$ が閾值温度を超えたものの強度 ・ 自己収縮が, 温度降下以降 に停滞する理由を考察する。石田ら ${ }^{23}$ は, 水和が十分に進行したぺ 一ス卜硬化体を対象に, 水の移動速度の温度依存性に着目し,「イン クボトル空隙中に存在する自由水は, 高温条件下で熱力学的不安定 さ故に徐々に逸散する」と仮説を立て, 実験・解析的に検証している。 この仮説は本現象の理由を説明しうるものである。すなわち, 温度 上昇過程において閾值温度に達すると, 空隙の連続性が著しく低下 し, 空隙内の物質移動性は幾何学的に低下寸る。しかし高温（熱力 学的エネルギーが高い状態) であれば, 水は熱力学的平衡状態に向 かい移動を続けるため, 反応は停滞しない。一方, 温度降下寸ると 水はインクボトル空隙中に凝縮する（閉じ込められる）ため反応が 停滞し, 強度・自己収縮増進が停滞寸ると説明できる。また, 常温 下でもインクボトルのネックが完全に閉じていなければ, 微細空隙 中の自由水は時間をかけて移動し, 常温条件でも反応は緩やかに進 行寸ると考えられる。これが $T_{\max }=60^{\circ} \mathrm{C}$ 条件で強度・自己収縮が温 度降下以降緩やかに増進する理由である。一方, $T_{\max }=90^{\circ} \mathrm{C}$ 条件では 温度降下以降, 結合水率が増加する（反応は停止していない）もの の自己収縮は殆ど変化が無い。この理由は, 空隙の不連続性・独立 性が更に高まり自由水の移動が著しく制限されること, また硬化体 の強度が相当に高く収縮しない（変形出来ない）等, 複数の要因が 考えられる。以上の議論を模式化したものが図 9 である。

なお，既報 ${ }^{12}$ 2) 6) に示寸ように $T_{\max }=90^{\circ} \mathrm{C}$ 条件の温度履歴であって も温度降下が早いとそれ以降の強度・自己収縮は緩やかに増進寸る。 つまり, 図 9 の $T_{\max }=90^{\circ} \mathrm{C}$ 条件のような特性を得るには $T_{\max }=90^{\circ} \mathrm{C}$ でかつ所定の期間高温条件を続ける必要があることを付記する。

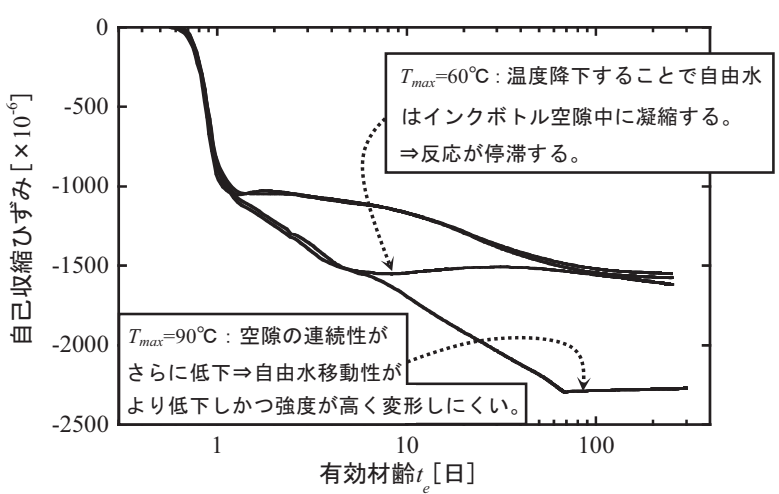

図 9 温度降下以降の自己収縮の停滞（模式図）

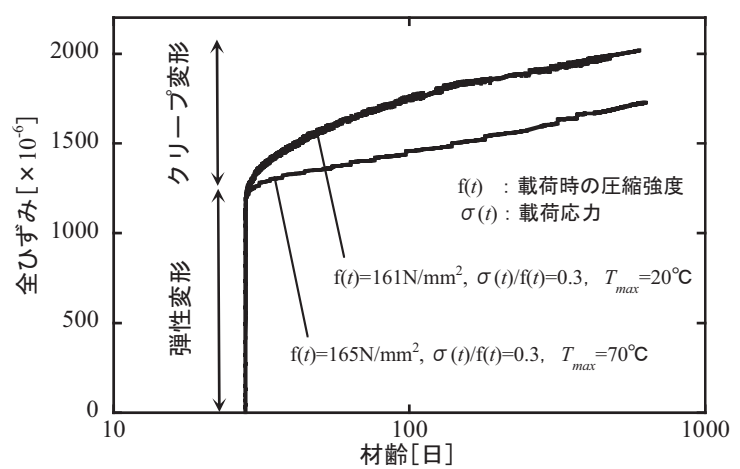

図 10 初期高温履歴の異なる超高強度コンクリートの 圧縮変形性状 ${ }^{3}$ 飞加等

\section{2 初期高温履歴による空隙構造変化と圧縮変形特性との関係}

図 10 は, 超高強度コンクリートを対象に, 圧縮強度が同等で初期 高温履歴の異なる $\left(T_{\max }=20\right.$ と $\left.70^{\circ} \mathrm{C}\right) 2$ 種類の水準で実施した圧縮

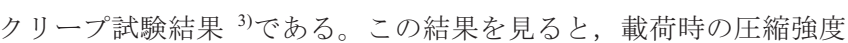
と弾性変形量が同等でも, $T_{\max }=70^{\circ} \mathrm{C}$ 条件のクリープ変形は載荷初期 において $T_{\max }=20^{\circ} \mathrm{C}$ 条件に比べ進行速度が遅く, 載荷材齢 600 日でも $T_{\max }=20^{\circ} \mathrm{C}$ 条件の $60 \%$ 程度と小さい。この理由を考察する。

圧縮変形性状一の空隙寸法と水の沴出の影響を検討した既往の研 究 ${ }^{24)}$ によると, $\mu \mathrm{m}$ レベルの空隙中の自由水の移動は載荷後短時間 で完了寸るため弾性域の挙動に支配的である。一方， $\mathrm{nm}$ レベル以 下の空隙中の自由水の移動は載荷後長時間かけ進行するためクリー プ変形挙動に支配的である。また, 超高強度コンクリートに限らず, 圧縮強度と静弾性係数との関係は初期高温履歴に影響されない 2) 25)。 以上と本研究結果から, 前述の現象は以下の理由で説明される。

1) $50 \mathrm{~nm}$ 以上の連続空隙量は $T_{\max }$ によらず同等なので, その領域で の自由水の移動性は同じである。そのため, 変形速度の速い弾性 変形量は閾值温度にかかわらず同等である。

2) $T_{\max }$ が閾值温度を超えた超高強度コンクリートは, $50 \mathrm{~nm}$ 以下の空 隙に存在する自由水が空隙外に滲出しにくい。その結果, 圧縮ク リープの進行速度が遅くなる。

5. $\mathrm{N}_{2}$ および He 分子が浸入出来ない空隙と「結合していない水」 5. $1 \mathrm{~N}_{2}$ および He 分子が浸入出来ない空隙

3.2 および 3.3 で， $90^{\circ} \mathrm{C}$ 到達後は「 $\mathrm{N}_{2}$ および $\mathrm{He}$ 分子が浸入出来な い微細な空隙が多量に形成される」ことを考察し, $T_{\max }=20,45,60^{\circ} \mathrm{C}$ 

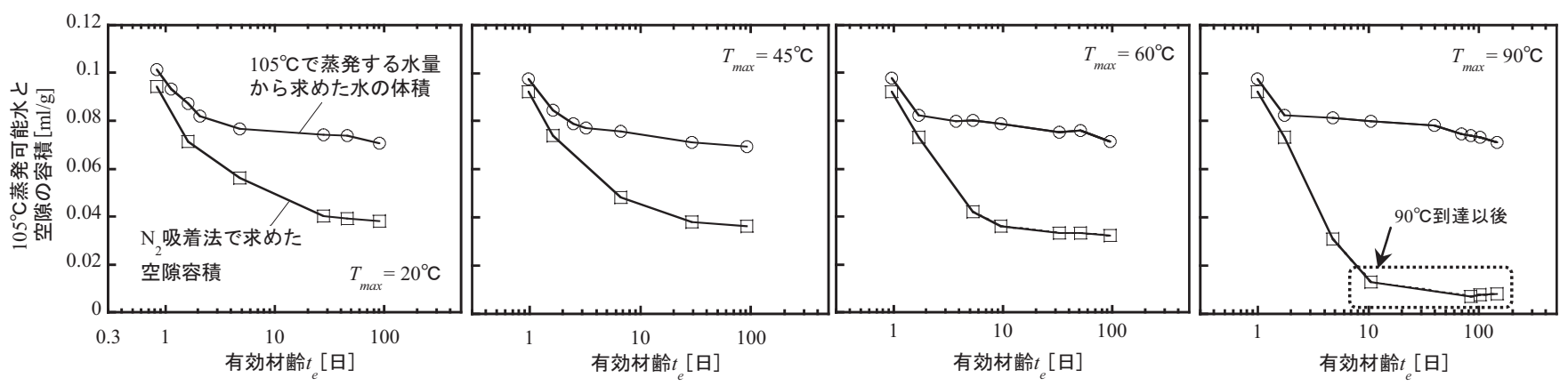

図 11 恒量まで $105^{\circ} \mathrm{C}$ 乾燥した際の蒸発水量から求めた水の体積と窒素ガス吸着法で測定した空隙容積

表 4 分子動力学的半径 ${ }^{12)}$

\begin{tabular}{c|c|c|c}
\hline & $\mathrm{N}_{2}$ & $\mathrm{He}$ & $\mathrm{H}_{2} \mathrm{O}$ \\
\hline $\begin{array}{c}\text { 分子寸法 } \\
(\mathrm{nm})\end{array}$ & 0.364 & 0.260 & 0.265 \\
\hline
\end{tabular}

条件では「空隙構造は微細空隙が埋まりつつ粗大な空隙が独立的に 残存する」ことを述べた。ここで,「セメント硬化体は水和物が立体 的に組み合わされ形成される」との前提に立つと, $T_{\max }=20,45,60^{\circ} \mathrm{C}$ 条件でも「微細空隙を全く形成せずに反応が進行する」とは考えにく い。 $\mathrm{nm}$ レベル以下の視点で見て, 反応の進行につれ $T_{\max }$ によらず $\mathrm{N}_{2}$ 分子や $\mathrm{He}$ 分子が浸入不可能な空隙が形成されると推論できる。

本研究で得られた, 恒量まで $105^{\circ} \mathrm{C}$ 乾燥した際の蒸発可能水(「調 合上の水量」一「結合水量」に相当）の体積と $\mathrm{N}_{2}$ 吸着法（吸着側）に よる空隙容積の測定結果 (試料乾燥質量に対する比率) を図 11 に示 す。蒸発可能水体積は乾燥質量減少量より密度を $1.0 \mathrm{~g} / \mathrm{cm}^{3}$ として算 出した。ここで， $\mathrm{N}_{2}$ 吸着法の空隙容積で $90^{\circ} \mathrm{C}$ 到達後の結果は, 3.2 の議論から「 $\mathrm{N}_{2}$ 分子が自身の寸法以上の空隙全てには到達せずに得 られた結果」であり,その他の測定結果と同様に全ての空隙容積を評 価できていない点に留意が必要である。この結果を見ると， $T_{\max }$ に よらず材齢の増加につれ $105^{\circ} \mathrm{C}$ で蒸発する水の体積が $\mathrm{N}_{2}$ 吸着法で求 めた空隙容積より大きくなり, $T_{\max }=20,45,60^{\circ} \mathrm{C}$ 条件では, 有効材 齢 100 日時点で前者は後者の 2 倍程度にもなる。この結果は, $\mathrm{H}_{2} \mathrm{O}$ 分子と $\mathrm{N}_{2}$ 分子それぞれで評価している空隙領域が異なることを示 唆するものである。このことから， $\mathrm{N}_{2}$ 分子が浸入出来ない空隙が存 在し，そこに蒸発可能水が存在することを推論できる。ここで, 蒸 発可能水体積の試料と $\mathrm{N}_{2}$ 吸着法の試料の前処理はそれぞれ，1) 蒸 発可能水: $105^{\circ} \mathrm{C}$ 乾燥 (恒量まで), 2$) \mathrm{N}_{2}$ 吸着法 : $105^{\circ} \mathrm{C}$ 乾燥 $(48$ 時 間), である (表 3)。本結果の理由が前処理方法の違いならば, 蒸 発可能水率の測定において恒量時の測定值が 48 時間での測定值の 2 倍以上となるはずだが，図 8 を見るとそうではない。従って，試料 の前処理方法の違いは本結果の原因ではない。また, $90^{\circ} \mathrm{C}$ 到達後は $\mathrm{N}_{2}$ 吸着法による空隙容積測定値が著しく低下寸るものの, 蒸発可能 水の体積は急激には変化しない。これは「 $\mathrm{N}_{2}$ 分子が浸入不可能な空 隙に囲まれた粗大空隙から $\mathrm{H}_{2} \mathrm{O}$ 分子が脱出した」結果と考えられ, このことからも $\mathrm{N}_{2}$ 分子が通過不可能で $\mathrm{H}_{2} \mathrm{O}$ 分子が通過可能な空隙 の存在を推論できる。

これまでにも, BET 比表面積の測定值は吸着質に窒素でなく水蒸 気を用いたほうが大きいことが議論されており,この理由に $\mathrm{N}_{2}$ 分子 の浸入出来ない微細空隙の存在が指摘されているをとえは2 262728)。既に 他の研究において, C-S-H は $\mathrm{N}_{2}$ 分子の浸入可否で 2 種類に分類出

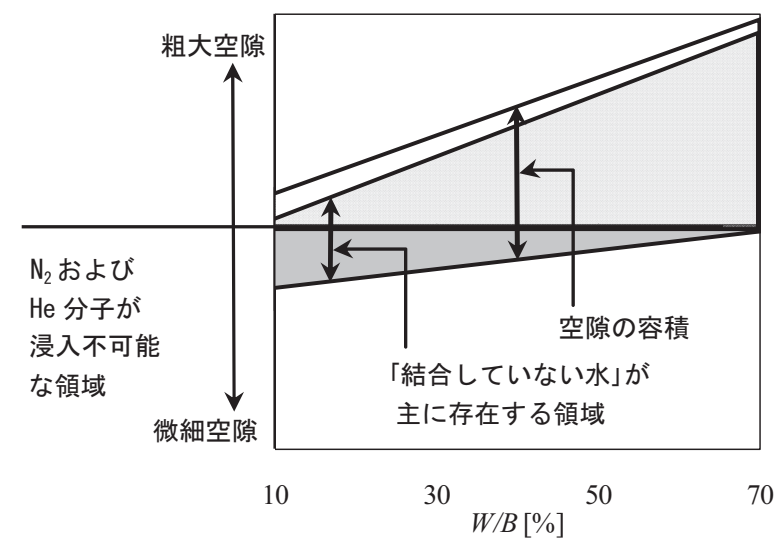

図 12 外部からの水の供給が制限される条件で長期的に反 応が進行したペースト硬化体の空隙構造と「結合していな い水」との関係（概念図）

来，水結合材比が低いほど $\mathrm{N}_{2}$ 分子が浸入出来ない C-S-H の割合は 高くなることが報告されている ${ }^{29)}$ 。また， $105^{\circ} \mathrm{C}$ 絶乾したペース卜 硬化体を, 水および半径 $3 \mathrm{~nm}$ 以下の空隙には浸入出来ない液体にそ

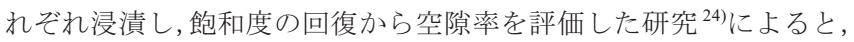
全空隙中における半径 $3 \mathrm{~nm}$ 以下の微細空隙の割合は $W / C$ が低いほ ど増加している。さらに, 吸着質に水蒸気を用いて超高強度硬化体 の BET 比表面積を測定した研究 ${ }^{30)}$ をると, 測定值は筆者らの窒素 を用いた結果（図1(c)）よりも明らかに大きい。

ここで $\mathrm{N}_{2}, \mathrm{He}, \mathrm{H}_{2} \mathrm{O}$ の分子動力学的直径 (kinetic diameter) ${ }^{12)}$ 比べると, 各気体分子の寸法は $\mathrm{He}<\mathrm{H}_{2} \mathrm{O}<\mathrm{N}_{2}$ である（表 4)。寸法 で評価した場合, $\mathrm{H}_{2} \mathrm{O}$ 分子の浸入可能な空隙に少なくとも $\mathrm{He}$ 分子 は浸入可能となり，本節の推論は成立しない。一方，無機膜による 気体分離技術分野の研究において, 細孔壁の親水性が高い場合に混 合気体中の $\mathrm{H}_{2} \mathrm{O}$ 気体分子は選択的に細孔を満たす（分離できる）こ とがわかっている ${ }^{31)}$ 。 $\mathrm{H}_{2} \mathrm{O}$ 分子が $\mathrm{N}_{2}$ と $\mathrm{He}$ 分子が通過出来ない空隙 に浸入できる理由には，超高強度硬化体の表面性状が親水性である ことが大きく寄与していると考えられる。

以上から，「反応の進行につれ $T_{\max }$ によらず $\mathrm{N}_{2}$ および $\mathrm{He}$ 分子の 浸入不可能な微細空隙が形成される」推論は確かであると考えられ る。また, 低 $W / B$ である超高強度硬化体では, そのような微細空隙 が全空隙容積に占める比率は通常のペースト硬化体よりも高いと考 えられる。上記の議論に, 3.3.1 で前述した「外部から水の供給が制 限される条件で反応が進行する場合, 空隙は粗大な領域から乾燥す る」,「反応に必要な水は低 $W / B$ 条件ほど微細な領域に存在寸る」を 考慮した概念を図 12 に示寸。この中で, $1105^{\circ} \mathrm{C}$ 蒸発可能水」は正確 


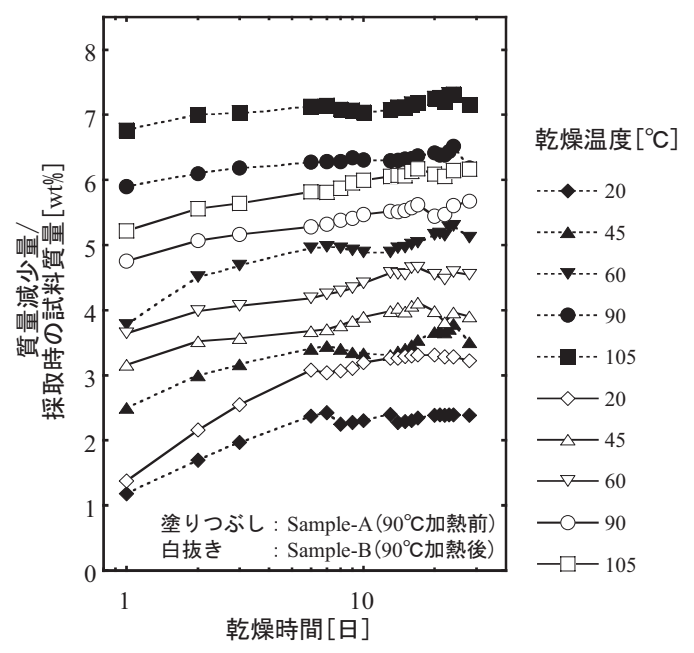

(a) 蒸発可能水量測定值の時間変化

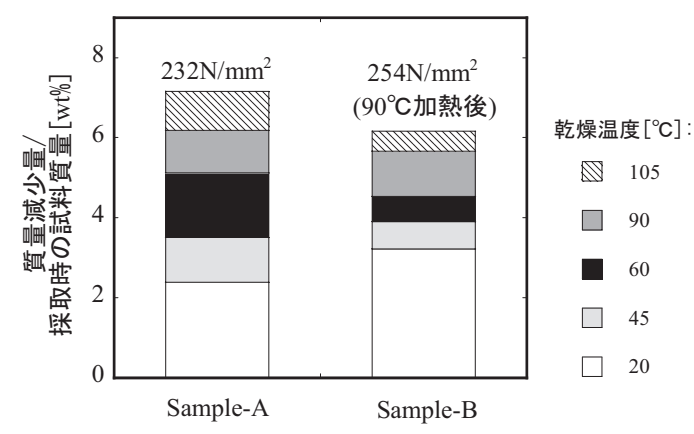

(b) 恒量時の蒸発可能水量と圧縮強度との関係

図 13 常温下の長期材齢超高強度硬化体における $90^{\circ} \mathrm{C}$ 加熱前後の蒸発可能水量変化と強度との関係

には自由水以外に吸着水や層間水が含まれるをとえば26)32)ことから, 自 由水でなく「結合していない水」と呼称する。超高強度硬化体は, 通 常のペースト硬化体よりも「結合していない水」が微細空隙に存在す る比率が高く, 吸着水と層間水の比率が高いと考えられる。

\section{2 「結合していない水」と強度・自己収縮増進との関係}

超高強度硬化体中には未反応結合材が残存している ${ }^{33} 343$ )35)。また 図 8 を見ると, $200 \mathrm{~N} / \mathrm{mm}^{2}$ に達した時点で $105^{\circ} \mathrm{C}$ 蒸発可能水（すなわ ち「結合していない水」) は 7.5\%(0.075) 程度である。調合上 $W / B=0.13$ であるから,この時点でも調合上の水量の半分以上が「結合していな い水」として存在する。これまでの考察によれば, 常温・封かん条件 で長期材齢であれば，「結合していない水」の多くはインクボトル状 の空隙中に凝縮する自由水, もしくは吸着水や層間水として安定す るため反応に寄与しにくく, 強度・自己収縮の増進は停滞する。こ の推論が妥当ならば,この時点で「結合していない水」を加熱する(す なわち熱力学的エネルギーを高める）と，1)それらは微細空隙から 脱出し，2)結合材と水和反応し，3)強度・自己収縮が更に増進する。 そこで本推論を検証すべく, 実験を行った。

本実験で作製した $T_{\max }=60^{\circ} \mathrm{C}$ の圧縮強度試験体を $20^{\circ} \mathrm{C}$ 封かん条件 (水分が逸散しない条件) で材齢 680 日まで長期養生したもの (Sample-A) および, Sample-A と同じ試験体を封かん条件のまま更 に 7 日間 $90^{\circ} \mathrm{C}$ 加熱した試験体（Sample-B）について，それぞれ 20, $45,60,90,105^{\circ} \mathrm{C}$ 条件下での蒸発可能水量を測定した。具体的には,

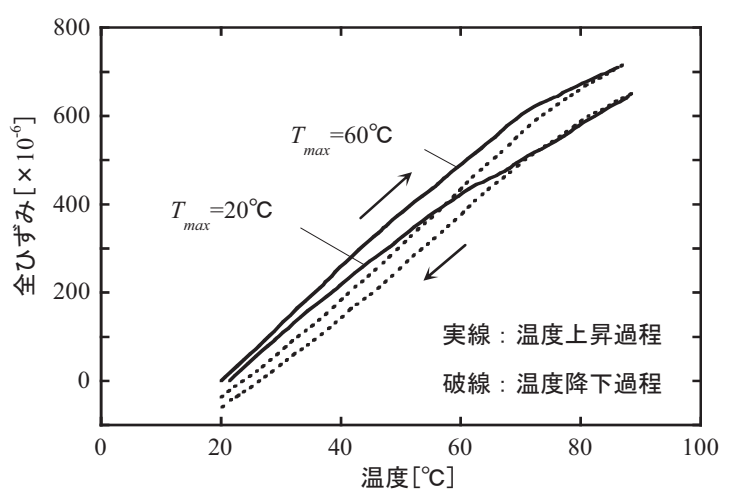

図 14 常温下の長期材齢超高強度コンクリート を $90^{\circ} \mathrm{C}$ 加熱した時の温度一全ひずみ関係

それぞれの試験体で圧縮試験を行い, 試験後の試料破片を粉砕・分 級（2.5-1.2mm） し，概放恒量まで（1 ケ月間）質量減少率（質量減 少量／採取時の試料質量[\%]）を測定した。Sample-A，B それぞれの 試料は, 乾燥温度の水準ごとに同じ環境下に存置した。45, 60, 90, $105^{\circ} \mathrm{C}$ 乾燥は所定温度に制御した乾燥炉内に, $20^{\circ} \mathrm{C}$ 乾燥は $20^{\circ} \mathrm{C}$ 室 内でデシケータ中に試料と乾燥剤を存置することで実施した。乾燥 中の雰囲気相対湿度（実測值）は $20^{\circ} \mathrm{C}: 5 \sim 8 \%, 45^{\circ} \mathrm{C}:$ 約 $1 \sim 7 \%$, $60^{\circ} \mathrm{C}: 0 \sim 3.5 \%, 90^{\circ} \mathrm{C}: 0 \%$ あっった。測定結果を図 13 に示す。「微 細な領域に存在する水ほど蒸発しにくい（高温で蒸発する）」前提の もと, 以下考察する。

1) 加熱することで， $20 ， 45^{\circ} \mathrm{C}$ で蒸発する水量が明らかに増加した。

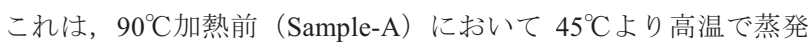
する「結合していない水」の一部が, 加熱されることで(Sample-B) $45^{\circ} \mathrm{C}$ 以下の条件で蒸発可能な状態となった(すなわち微細空隙か ら脱出した）ためと考えられる。

2) 加熱することで， $60 ， 90,105^{\circ} \mathrm{C}$ で蒸発する水量は減少した。こ のとき, 強度は $232 \mathrm{~N} / \mathrm{mm}^{2}$ から $254 \mathrm{~N} / \mathrm{mm}^{2}$ まで増進した。これは 「結合していない水」の一部が未反応結合材との水和反応に使わ れた（すなわち水和反応が進行した）ためと考えられる。

3) 加熱前において, $45^{\circ} \mathrm{C}$ より高温で蒸発可能な水量は, $105^{\circ} \mathrm{C}$ で蒸 発する水量の半分以上を占める。一方図 11 を見ると, 長期材齢 では $\mathrm{N}_{2}$ 分子が浸入不可能な微細空隙の容積は「結合していない 水」の体積の半分程度である。すなわち, $45^{\circ} \mathrm{C}$ より高温で蒸発 可能な「結合していない水」の多くは $\mathrm{N}_{2}$ 分子が浸入不可能な空隙 中に存在すると推察される。

4）材齢 91 日から 680 日にかけての強度も $209 \mathrm{~N} / \mathrm{mm}^{2}$ から $232 \mathrm{~N} / \mathrm{mm}^{2}$ まで増進している（91 日強度は図 1(b)a）参照)。つまり，常温 条件でも長期的に反応は継続する。

また, 図 14 は既報 ${ }^{1)}$ で示した初期高温履歴を与えた超高強度コン クリート自己収縮試験体 $\left(W / B=0.14, T_{\max }=20,60^{\circ} \mathrm{C}\right)$ を， $20^{\circ} \mathrm{C}$ 封 かん条件で 600 日まで養生し, その後に封かん条件のまま $90^{\circ} \mathrm{C}$ の温 度履歴を与えた温度-全ひずみ測定結果である。各試験体の全ひずみ には加熱前時点では時間変化が見られなかった(停滞していた)が, 加熱前後で $T_{m a x}=20,60^{\circ} \mathrm{C}$ それぞれ $60,36 \times 10^{-6}$ の収縮ひずみが観測 された。図 13 で示したように, 同様の試験体を封かん条件で $90^{\circ} \mathrm{C}$ 加熱すると水和反応が進行することから，図 14 における $90^{\circ} \mathrm{C}$ 加熱 前後の収縮挙動は自己収縮によるものと考えられる。以上の結果は, 
本節の冒頭に示した推論を裏付けるものである。

本研究と同じコンクリートを対象に筆者らが別途実施した実験 ${ }^{36}$ をはじめ, その他の研究でも強制的に加熱し続けることで, 超高強 度コンクリートの強度は増進することがわかっているたとえば33137)。 の理由は，加熱することにより微細空隙に凝縮して閉じ込められた 「結合していない水」の熱力学的エネルギーを高め, 微細空隙から の移動を可能にして水和反応に寄与させることができるからと考え られる。超高強度硬化体の強度・変形特性メカニズムを厳密に説明 するには, nm レベル以下の微細空隙の構造とそこに存在する「結合 していない水」のふるまいを明らかにすることが今後重要な課題で ある。

\section{6. まとめ}

本研究では, ポルトランドセメントにシリカ質微粉末を混入した 結合材を用いた超高強度硬化体の強度・变形特性が初期高温履歴に より変化する理由を, 空隙構造と水分移動の観点から議論した。得 られた知見と考察結果を以下に記述する。

1) 超高強度硬化体の空隙構造は, 初期高温履歴の最高温度 $T_{\max }$ が特 定の閾值温度に達した時点で不連続的に変化する。その変化は直 径で概ね $50 \mathrm{~nm}$ 以下の微細空隙に現れる。閾值温度に達した時点 で常温条件では埋まらない領域が埋まり, 連続性が低下寸る。そ の結果, 自由水は温度降下後にインクボトル空隙中に凝縮し, 移 動性が低下寸ると考えられる。

2) $T_{\max }$ が閾值温度を超えた超高強度硬化体の強度・自己収縮の増進 は, 温度が降下寸ると停滞する。その理由は, 初期高温履歴によ り空隙構造が変化し, 自由水がインクボトル空隙中に凝縮して反 応に寄与しにくくなるためと考えられる。

3) 超高強度硬化体の圧縮変形特性について, $T_{\max }$ が閾值温度を超え たものと超えなかったものと比べると, 弾性変形量は両者で同等 な一方, クリープ進行速度は $T_{\max }$ が閾值温度を超えたものの方が 遅い。この理由は, 初期高温履歴により空隙構造が変化し, 微細 空隙中の自由水が空隙外に渗出しにくくなるためと考えられる。

4) 超高強度硬化体の空隙構造は, $90^{\circ} \mathrm{C}$ を超えかつ所定期間高温で養 生されることで, 空隙構造がさらに複雑となり, 空隙の連続性が 著しく失われ独立性が高まる。この理由は， $\mathrm{N}_{2}$ および $\mathrm{He}$ 分子が 浸入出来ないほどの微細な空隙構造が多量に形成されるためと 考えられる。

5) 超高強度硬化体は, 総空隙量における「 $\mathrm{N}_{2}$ および $\mathrm{He}$ 分子が浸入 不可能で $\mathrm{H}_{2} \mathrm{O}$ 分子が浸入可能な微細空隙」の比率が通常のセメン 卜硬化体よりも高く, その中に「結合していない水 $\left(105^{\circ} \mathrm{C}\right.$ で蒸発 可能な水)」が存在する。温度降下後に再度加熱もしくは強制的に 加熱時間を延長することで,「結合していない水」は微細空隙に凝 縮することなく結合材と反応し, 強度・自己収縮が増進すると考 えられる。

\section{7. 今後の検討課題}

超高強度硬化体の強度・変形特性メカニズムをより厳密に説明す るには, $\mathrm{nm}$ レベル以下の微細空隙構造とそこに存在する「結合して いない水」のふるまいを解明する研究が重要と考えられる。また, 本 研究の対象範囲を広げ,「高温履歴」「シリカ質微粉末の混入」「超低
水結合材比」の 3 つの要因が独立・複合して作用した場合の水和物, 空隙構造，水分状態に及ぼす影響を $\mathrm{nm}$ 以下のレベルで検証するこ とで，超高強度に限らずコンクリートの強度・自己収縮，圧縮変形 特性が少なからず明らかになると考えられる。

\section{謝辞}

本研究の実施にあたり，東京大学生産技術研究所 岸利治教授，東 京大学大学院工学系研究科 石田哲也准教授に御助言をいただきま した。また，(株住化分析センターの緒方博彰氏より分析試験につい て御助言を頂き, 日本シ一力侏の関係各位より化学混和剤の提供な らびに実験への御協力を頂きました。ここに記して感謝いたします。

\section{参考文献}

1) 松田拓，野口貴文，蓮尾孝一，小出貴夫，鈴木康範：初期高温履歷を受 ける超高強度コンクリートの自己収縮特性および予測手法, 日本建築学 会構造系論文集, No.652,pp.1047-1055, 2010.6

2) T. Matsuda, H. Kawakami, T. Koide and T. Noguchi : Development of Mechanical Properties of Ultra-High-Strength Concrete Subjected to Early Heat Curing, Journal of Advanced Concrete Technology Vol. 7, pp.183-193, 2009. 6

3) 松田拓, 河上浩司, 西本好克 : 超高強度コンクリートのクリープ特性に 関する実験的研究, コンクリート工学論文集, Vol.19, No.2, pp.11-19, 2008

4) 片寄哲務，横須賀誠一，西田浩和，佐々木仁：初期高温履歴を受けた超 高強度コンクリートの圧縮クリープ性状，コンクリート工学年次論文報 告集, Vol.29, No.2, pp.115-120, 2007

5) 菅田紀之, 佐藤克俊, 鎌田健太郎：高強度コンクリートの圧縮クリーブ に及ぼす初期高温履歴の影響, セメント・コンクリート論文集, No.55, pp.494-499, 2001

6) 松田拓, 野口貴文, 蓮尾孝一，小出貴夫，鈴木康範： $200 \mathrm{~N} / \mathrm{mm}^{2}$ 級超高強 度コンクリートの強度・自己収縮特性における初期高温履歴の影響メカ ニズム, 日本建築学会構造系論文集, No.666, pp.1383-1392, 2011.8

7) 松田拓, 野口貴文, 蓮尾孝一, 小出貴夫 : 初期高温履歴による $200 \mathrm{~N} / \mathrm{mm}^{2}$ 級超高強度コンクリートの反応生成物変化及び強度・自己収縮増進特性 への影響, 第 65 回セメント技術大会講演要旨, pp.62-63, 2011

8）松田拓，野口貴文，蓮尾孝一，小出貴夫 : $200 \mathrm{~N} / \mathrm{mm}^{2}$ 級超高強度コンクリ 一トの一軸拘束挙動に及ぼす初期高温履歴の影響, 第 65 回セメント技術 大会講演要旨, pp.64-65, 2011

9) 小出貴夫, 小林哲夫, 松田拓, 蓮尾孝一: 初期高温履歴の異なる $200 \mathrm{~N} / \mathrm{mm}^{2}$ 級超高強度ペースト硬化体の物性に関する一検討, 第 65 回セメント技術 大会講演要旨, pp.66-67, 2011

10) 近藤精一, 石川達雄, 安部郁夫 : 吸着の科学, 丸善株式会社, pp.64-65, 2001

11) 今本啓一：比表面積と細孔量に基づくセメント系材料の収縮挙動に関す る一考察, コンクリート工学年次論文報告集, Vol.29, No.1, pp.603608, 2007

12) John Wiley \& Sons Ltd.,: Material science of membranes for gas and vapor separation, p.6, 2006

13) 岸利治, 吉田亮 : 硬化セメントペーストが内包する複数のインクボトル 幾何構造に関する研究, 生産研究, 60 巻第 5 号, pp122-125, 2008

14) 小野嘉夫，鈴木勲：吸着の科学と応用，講談社，p.76，2003

15) 内川浩, 羽原俊祐, 沢木大介 : 混合セメントモルタル及びコンクリート の硬化体構造が強度発現性状に及ぼす影響, セメント・コンクリート論 文集，No.44，pp.330-335, 1990

16) 大池武, 中根淳, 喜田大三, 斉藤祐司：シリカフューム混入セメントペ 一ストの高温履歷による強度発現特性と微細構造に関する実験的研究, コンクリート工学年次論文報告集, 12-1, pp.237240, 1990

17) 多田眞作: 水系の熱力学, セメント・コンクリートNo.476, pp.8-16, 1986.10

18) 藤井欽二郎：けい酸三石灰，二石灰水和の反応速度論，昭和 53 年セメン 卜技術年報, pp22-28, 1978

19) 五十嵐心一，渡辺暁央，川村満紀：反射電子画像の画像解析によるセメ ントの水和度の推定と強度に関寸る一考察, コンクリート工学論文集, Vol.14, No.2, pp.23-29, 2003

20) 菅俣匠，小泉信一，原田健二，太田晃，水結合材比 $18 \%$ 以下の領域にお 
けるセメント-シリカフューム系結合材の水和反応と強度発現性に関する 一考察（その 2)，BASF ポゾリス開発・技術センターレポートNo.16, pp.9-19, 2007

21) 近藤精一, 石川達雄, 安部郁夫 : 吸着の化学, 丸善株式会社, pp.56-57, 2001

22) 半井健一郎, 石田哲也, 岸利治, 前川宏一 : セメント硬化体組織構造の 温度依存性に基づく熱力学練成解析の高度化, 土木学会論文集, No.802, V-69, pp.61-78, 2005, 11

23) 石田哲也, 前川宏一, 岸利治, 磐田吾郎, 楠原千佳子: 温湿度履歴に関 するセメント硬化体中水分平衡・移動モデルの高度化, 土木学会論文集, No.795, V-68, pp.39-53, 2005, 8

24) 浅本晋吾, 石田哲也 : 微細空隙中の液体特性に着目したコンクリートの 時間依存変形機構の検討，土木学会論文集，No.760, V-63, pp.159-172, 2004, 5

25) 堀口浩司, 長曽我部徹, 大塚昭男, 鈴木康範 : 各種セメントを用いたコ ンクリートの高温養生強度, セメント・コンクリート論文集, No.47, 1993

26) R.F. Feldman and P.J. Sereda: A model for hydrated Portland cement paste as deduced from sorption-length change and mechanical properties, Materials and Structures, Vol.1, pp.509-520, 1968

27) Daimon M., Abo-El-Enein, S. A., Hosaka, G., Goto, S. and Kondo, R: Pore structure of calcium silicate hydrate in hydrated tricalcium silicate, Journal of American Ceramic Society, Vol.60, pp.110-114, 1977

28) 近藤連一：多孔材料一性質と利用一, 技報堂出版株式会社, p. 325,1973

29) P.D. Tennis and H.M. Jennings: A model for two types of calcium silicate hydrate in the microstructure of Portland cement pastes, Cement and Concrete Research, Vol.30, pp.855-863, 2000
30) 寺本篤史, 丸山一平, 三谷裕二, 谷村充 : 低水結合材比シリカフューム ペーストの自己収縮性状に関寸る研究, コンクリート工学年次論文報告 集, Vol.31, No.1, pp.601-606, 2009

31) K. Aoki, K. Kusakabe, and S. Morooka: Separation of gases with an A-type zeolite membrane, Industrial \& Engineering Chemistry Research 39, pp.2245-2251, 2000

32) T.C.Powers: Mechanisms of Shrinkage and Reversible Creep of Hardened Cement Paste, Proc. Of Int. Conf. On the Structure of Concrete and its Behaviour Under Load, Cement and Concrete Association, pp.319-344, 1695

33 ) 小泉信一, 菅俣匠, 栘田佳寛: $200 \mathrm{~N} / \mathrm{mm}^{2}$ 級超高強度コンクリートの強度 発現性に及ぼすシリカフュームの温度依存性, 日本建築学会構造系論文 集, Vol.76, No.659, pp.15-22, 2011.1

34) 石中正人，中山英明，成瀬浩康：シリカフューム混合セメントにおける 加熱養生時の強度発現性に及ぼす最高温度の影響, コンクリート工学年 次論文報告集, Vol.30, No.2, pp.91-96, 2008

35) 三谷裕二, 番地成朋, 谷村充, 丸山一平: 高温度履歴を受けた低水結合 材比シリカフューム混和セメントの強度および水和反応特性, コンクリ 一ト工学年次論文報告集, Vol.31, No.1, pp.1495-1500, 2009

36) 松田拓, 蓮尾孝一, 柴田要, 小出貴夫, 松丸真, 勝呂昇 : $200 \mathrm{~N} / \mathrm{mm}^{2}$ 級超 高強度 PCa コンクリートの検討, 日本建築学会大会学術講演梗概集, 材 料施工 pp.993-994, 2010

37) 渡邊悟士, 陣内浩, 黒岩秀介, 山本佳城, 並木哲, 寺内利恵子：設計基 準強度 $200 \mathrm{~N} / \mathrm{mm}^{2}$ の超高強度コンクリートの開発に関する検討, 日本建築 学会大会学術講演梗概集, 材料施工 pp.1077-1078, 2008.9

（2012年 4 月 10 日原稿受理， 2012年 8 月 20 日採用決定） 